\title{
Therapeutic Protection from Hepatic Injury and Chemical Constituents of Buchanania angustifolia Roxb
}

\author{
Buchanania angustifolia Roxb'un Kimyasal Bileşenleri ve Karaciğer \\ Hasarına Karşı Terapötik Koruyucu Etkisi
}

\author{
(D) Mallikarjuna Rao TALLURI', (D) Rajananda Swamy TADI²*, (D) Ganga Rao BATTU² \\ 'AnaCipher Clinical Organisation, Telangana, India \\ ${ }^{2}$ Andhra University, College of Pharmaceutical Sciences, Department of Pharmacognosy and Phytochemistry, Andhra Pradesh, India
}

\begin{abstract}
Objectives: The use of modern medicines in the treatment of diseases instead of traditional medicine is causing different adverse effects. Therefore, there is need to search new bioactive compounds to treat different diseases. Buchanania angustifolia has been used in traditional medicine in the treatment of different diseases. On the basis of folkloric information, $B$. angustifolia aerial parts extracts have been selected for their antioxidant and hepatoprotective potentiality and phytochemical constituents.

Materials and Methods: Qualitative phytochemical screening of B. angustifolia extracts revealed the presence of phytochemical constituents such as steroids, terpenoids, flavonoids, alkaloids, glycosides, tannins, carbohydrates, oils and amino acids. BA-1 and BA-2 compounds isolated from hydroalcoholic extract using chromatography and were identified as linolenic acid and mixture of stigmasterol and $\beta$-sitosterol.

Results: Antioxidant activity was performed on superoxide, hydroxyl and 1-(2,6-dimethylphenoxy)-2-(3,4-dimethoxyphenylethylamino) propane hydrochloride free radicals. The $B$. angustifolia extracts showed dose-dependent activity on free radicals. The hydroalcoholic extract showed better activity. The extracts showed hepatoprotective activity on thioacetamide-induced liver intoxication in rats, and hydroalcoholic extract exhibited significant restoration of the altered biochemical parameters due thioacetamide-induced liver intoxication.

Conclusion: Among the tested extracts of $B$. angustifolia, hydroalcoholic extract showed higher antioxidant and hepatoprotective activity and stigmasterol and $\beta$-sitosterol were isolated. Further research is needed to evaluate other pharmacological activities and to isolate the other bioactive compounds from $B$. angustifolia.
\end{abstract}

Key words: Buchanania angustifolia, chemical constituents, antioxidant activity, thioacetamide, hepatoprotective activity

Amaç: Hastalıkların tedavisinde geleneksel tıp yerine modern ilaçların kullanımı farklı yan etkilere neden olabilmektedir. Bu nedenle, çeşitli hastalıkların tedavisinde kullanılmak üzere yeni biyoaktif bileşiklerin araştırılması gerekmektedir. Buchanania angustifolia, geleneksel tıpta farklı hastalıkların tedavisinde kullanılmaktadır. Bu çalıșmada, folklorik bilgilere dayanılarak, B. angustifolia bitkisinin toprak üstü kısımlarının antioksidan ve hepatoprotektif etkilerinin ve fitokimyasal bileşenlerinin belirlenmesi amaçlanmıştır.

Gereç ve Yöntemler: B. angustifolia ekstreleri üzerinde yapılan kalitatif fitokimyasal analizler, ekstrelerde steroit, terpenoit, flavonoit, alkaloit, glikozit, tanen, karbonhidrat, yağ ve aminoasit yapısındaki bileşiklerin varlığını ortaya koymuştur. BA-1 ve BA-2 bileşikleri kromatografik teknikler kullanılarak sulu alkollü ekstreden izole edilmiş ve linolenik asit ile stigmasterol ve $\beta$-sitosterol karışımı olarak tanımlanmıştır.

Bulgular: Antioksidan aktivite, süperoksit, hidroksil ve 1-(2,6-dimetilfenoksi)-2-(3,4-dimetoksifeniletilamino) propan hidroklorit serbest radikalleri üzerinde gerçekleştirilmiştir. B. angustifolia ekstreleri, serbest radikallere karşı doz-bağımlı aktivite göstermiştir. Sulu alkollü ekstrenin daha iyi aktivite gösterdiği belirlenmiştir. Ekstreler sıçanlarda tiyoasetamid-nedenli karaciğer zehirlenmesinde hepatoprotektif etki göstermiş ve sulu alkollü ekstre, tiyoasetamid-nedenli karaciğer zehirlenmesine bağlı olarak değişen biyokimyasal parametreleri anlamlı derecede iyileştirmiştir.

Sonuç: B. angustifolia'nın test edilen ekstreleri arasında sulu alkollü ekstrenin daha yüksek antioksidan ve hepatoprotektif etkinlik gösterdiği belirlenmiştir ve stigmasterol ve $\beta$-sitosterol bileşikleri izole edilmiştir. B. angustifolia'nın diğer farmakolojik etkilerinin değerlendirilmesi ve başka biyoaktif bileşiklerinin izolasyonları için daha fazla araştırmaya ihtiyaç duyulmaktadır.

Anahtar kelimeler: Buchanania angustifolia, kimyasal bileşenler, antioksidan aktivite, tiyoasetamid, hepatoprotektif aktivite

*Correspondence: E-mail: rajaphd2015@gmail.com, Phone: +919490052637 ORCID-ID: orcid.org/0000-0003-1183-4070

Received: 02.04.2017, Accepted: 08.06.2017

Turk J Pharm Sci, Published by Galenos Publishing House. 


\section{INTRODUCTION}

Plants have been used as medicines since time immemorial around the world. The best known uses of plants in medicine were ayurveda in India, African traditional medicines, Unani medicine in Middle East countries, and in traditional Chinese medicine. ${ }^{1-5}$ The major problems associated with traditional medicine are the lack of standardization, consistency, safety, and quality. ${ }^{6}$ Advances in technology provided the perfection in medicine for treating the different diseases. Simultaneously, the use of modern medicine offered a new adverse effects with their long-term use and disease-causing microorganisms gaining resistance to drugs. ${ }^{7,8}$ As such, people are turning back to traditional medicine because of their fewer adverse effects and the diversity of chemical entities in them for the treatment of different diseases. From this point of view, researchers are now focusing on the identification, evaluation, and standardization of the biologic activities of traditional medicinal plants ${ }^{9}$ using advanced technology to isolate new bioactive molecules. The present work was performed on one of the traditional medicinal plants, Buchanania angustifolia Roxb (B. angustifolia), to isolate new bioactive molecules and to provide scientific evidence of its traditional use by Indian tribes for a wide range of ailments, including nutritional disorders, skin diseases, gravel, healing of wounds, rheumatic pain, tonic for sexual debility, and urinary problems..$^{10-12} B$. angustifolia is mainly grown in dry deciduous forests and distributed around South India and Sri Lanka regions. However, to the best of our knowledge, the phytochemical constituents and biologic activities of $B$. angustifolia have not been reported. ${ }^{13}$ Therefore, this study was planned to investigate the phytochemical constituents, antioxidant, and hepatoprotective potentials of hexane, ethyl acetate, and hydroalcoholic extracts of $B$. angustifolia aerial parts.

\section{EXPERIMENTAL}

\section{Drug and chemicals}

Chemicals used for the study were analytical grade. Silymarin, thioacetamide (TAA) and 1-(2,6-dimethylphenoxy)-2-(3,4dimethoxyphenylethylamino) propane hydrochloride (DPPH) were purchased from Sigma-Aldrich, St. Louis, USA, nitroblue tetrazolium was purchased from Sisco Research Laboratories Pvt. Ltd., Mumbai, India. Riboflavin was purchased from Loba Chemie Pvt. Ltd., Mumbai, India. The kits for assessment of different biochemical parameters such as aspartate aminotransferase (AST/SGOT), alanine aminotransferase (ALT/ SGPT), alkaline phosphatase (ALP), total bilirubin, and total protein were purchased from Span diagnostics Ltd., Gujarat, India. Folin-Ciocalteu reagent, bromocresol green were purchased from Sigma-Aldrich, St. Louis, USA.

\section{Plant material collection and preparation of extracts}

The plant material was collected from the Talakona forest region, Tirupathi, Andhra Pradesh, India, during the month of December, 2010 (AUCP/BGR/2010-431). Authentication of the plant was performed by Rtd. Prof. M. Venkaih, Department of Botany, Andhra University, Visakhapatnam. The plant material was dried under shade and powdered for separate extraction processes using maceration with hexane, ethyl acetate, and hydroalcoholic [ethanol $(70 \% \mathrm{v} / \mathrm{v})$ ], and then concentrated to dryness under vacuum using rotavapour.

\section{Preliminary phytochemical studies}

The extracts of the $B$. angustifolia were subjected to different phytochemical tests for the identification of its phytochemical constituents, using standard procedures. ${ }^{13}$

\section{Quantification of total phenolic content}

The total phenolic content was determined using FolinCiocalteu reagent. The method is based on blue light absorption measurement due to the chemical reduction of tungsten and molybdenum oxides of Folin-Ciocalteu reagent, when combined with the compounds present in the extracts using colorimetry at $765 \mathrm{~nm}$. The phenolic content in the extract was measured in gallic acid equivalents as $\mathrm{mg} / \mathrm{g}$, using a gallic acid calibration curve. The results are shown in mean values. ${ }^{14,15}$

\section{Quantification of total alkaloid content}

The plant extract $(1 \mathrm{mg} / \mathrm{mL})$ was dissolved in $2 \mathrm{~N}$ hydrochloric acid and the solution was filtered. The phosphate buffer's $\mathrm{pH}$ was neutralized to $0.1 \mathrm{~N}$ sodium hydroxide. One milliliter of extract solution, $5 \mathrm{~mL}$ of phosphate buffer, and $5 \mathrm{~mL}$ of bromocresol green solution were placed in separation and then the solution was mixed well. The complex formed in the solution was extract with chloroform. The absorbance of complex color in chloroform was measure at $470 \mathrm{~nm}$. The experiment was performed in triplicate and results were reported in atropine equivalents. The results are presented as mean values. ${ }^{14,16}$

\section{In vitro antioxidant activity}

In vitro antioxidant activity was assessed use prepared extracts of $B$. angustifolia with dimethyl sulfoxide as a vehicle on superoxide, hydroxyl and DPPH free radicals. ${ }^{14,17,18}$ The percentage inhibition and inhibition concentration $(\mathrm{IC})_{50}$ values were calculated.

\section{Superoxide radical scavenging activity}

The superoxide scavenging activities of the selected plant extracts were evaluated as per standard methods, using absorption of light at $560 \mathrm{~nm}$, induction of superoxide free radical generation by riboflavin, and corresponding reduction by nitroblue tetrazolium.

\section{Hydroxyl radical scavenging activity}

The scavenging activity of selected plants extracts on hydroxyl radical was measured as per established methods. It was studied by the competition between deoxyribose and the extract's antioxidant molecules for hydroxyl radicals generated from the $\mathrm{Fe}+2 / E D T A / H_{2} \mathrm{O}_{2}$ system.

\section{$D P P H$ radical scavenging activity}

The DPPH radical scavenging activity was measured as per methods. This method is based on measurements of color absorbance of alcoholic DPPH solution (blue color) after adding the antioxidant solution (extract/compound). If antioxidants are present in the test compound, the blue color turns to yellow due to $\mathrm{DPPH}$. 


\section{Calculation of percentage inhibition}

The percentage inhibition of superoxide production by the extract was calculated using the following formula:

Inhibitory ratio $=\left(A_{0}-A_{1}\right) \times 100 / A_{0}$

$A_{0}$ : Absorbance of control, $A_{1}$ : Absorbance of plant extract or/ and ascorbic acid

$I_{50}$ calculation form percentage inhibition

The optical density obtained with each concentration of the extract/ascorbic acid was plotted taking concentration on the $\mathrm{X}$-axis and percentage inhibition on the $\mathrm{Y}$-axis. The graph was extrapolated to find the $50 \%$ inhibition concentration of extract/ ascorbic acid.

\section{Selection of animals}

Healthy albino rats of either sex weighing between 180-250 g aged 60-90 days were used for the study. The rats were taken care of with standard light and humidity and with a supply of proper food and water.

\section{Acute toxicity studies}

The acute toxicity study was conducted for extracts of $B$. angustifolia extracts as per Organisation for Economic Cooperation and Development (OECD) guidelines 420 (OECD 2001) and regulations of the Institutional Animal Ethics Committee (Regd no: 516/01/A/CPCSEA). The albino mice of single sex, were selected into three groups, each consisting of 6 animals. They were maintained for one week before the experiment under room temperature and allowed free access to food and water. The animals were subjected to an acute toxicity study using each extract at a dose of $2000 \mathrm{mg} / \mathrm{kg}$ orally at regular intervals of time, i.e., 1, 2, 4, 8, 12 and 24 h. During this time, the animals were under observation to note different conditions such as skin changes, morbidity, aggressiveness, oral secretions, sensitivity to sound and pain, respiratory movements, and mortality.

\section{Assessment of hepatoprotective activity of B. angustifolia}

The selected plant extracts were tested for their hepatoprotective nature using TAA-induced liver toxicity in rats. For this experiment, animals were divided into twelve groups of 6 animals. Group I was treated with normal saline (vehicle) for one week through oral administration at $2 \mathrm{~mL} / \mathrm{kg}$ body weight. Group II and Group III animals were treated with TAA as a 2\% $\mathrm{w} / \mathrm{v}$ solution in water on the first day at $50 \mathrm{mg} / \mathrm{kg}$ body weight subcutaneously (s.c.), then Group II was continuously treated with saline and Group III with silymarin at a dose of $25 \mathrm{mg} / \mathrm{kg}$ body weight p.o. for three weeks. Groups IV to XII were treated with TAA as a $2 \% \mathrm{w} / \mathrm{v}$ solution in water on the first day at 50 $\mathrm{mg} / \mathrm{kg}$ body weight s.c., then Groups IV, V, and VI were treated with hydroalcoholic extract, Groups VII, VIII, and IX with ethyl acetate extract, and Groups X, XI, and XII were treated with hexane extract at a doses of $125,250,500 \mathrm{mg} / \mathrm{kg}$ body weight orally for three weeks. Animals of all groups were anaesthetized using chloroform $48 \mathrm{~h}$ after the final dose of extracts. Blood samples were collected from the animal groups from the retroorbital plexus, then the samples were immediately centrifuged at $2400 \mathrm{rpm}$ for quarters of an hour. Then, the clearly separated serum after centrifugation was used for measuring the different biochemical parameters using an auto analyzer with reagent kits. ${ }^{19-21}$ All experimental procedures involving animals were conducted according to OECD guidelines and approved by the Institutional Animal Ethics Committee, Andhra University. Results were analyzed using Two-way ANOVA followed by the Bonferroni post-hoc test. All groups were compared with the silymarin group.

\section{Isolation of phytoconstituents (Compounds)}

There was very less phytochemical work reported on $B$. angustifolia. So, depends on availability of extracts after pharmacological study, hydroalcoholic extract of $B$. angustifolia was used for separation of compounds using column chromatography.

\section{RESULTS}

\section{Qualitative phytochemical screening}

Qualitative phytochemical screening of $B$. angustifolia extracts revealed the presence of different phytochemical constituents such as steroids, terpenoids, flavonoids, alkaloids, glycosides, tannins, carbohydrates, oils and amino acids. The extracts gave negative results for the quinines and saponins. All extracts of $B$. angustifolia revealed the presence of phenols, alkaloids, carbohydrates, steroids, terpenoids, and glycosides, and gave negative results to saponins. The hydroalcoholic and ethyl acetate extracts revealed the presence of flavonoids and tannins but the hexane extract gave negative results. The hexane and ethyl acetate extracts revealed the presence of a min amount of oil but hydroalcoholic extracts gave negative results. All extracts gave negative results to amino acids but the hydroalcoholic extracts give a weak positive result for the presence of amino acids (Table 1).

Table 1. Nature of phytoconstituents present in different extracts of B. angustifolia aerial parts

\begin{tabular}{llll} 
Phytochemical & \multicolumn{3}{l}{ Extracts of $B$. angustifolia aerial parts } \\
\cline { 2 - 4 } constituents & Hexane & Ethyl acetate & Hydroalcoholic \\
\hline Phytosterols & + & + & ++ \\
\hline Terpenoids & + & + & + \\
\hline Glycosides & + & ++ & ++ \\
\hline Saponins & - & - & - \\
\hline Flavonoids & - & + & + \\
\hline Tannins & - & + & + \\
\hline Carbohydrates & + & + & + \\
\hline Alkaloids & + & + & ++ \\
\hline Amino acids & - & - & + \\
\hline Oils & + & + & + \\
\hline Phenols & + & + & ++ \\
\hline
\end{tabular}

,+++ : Present, -: Absent 


\section{Quantification of phenolic and alkaloid contents}

The quantified phenolic contents of $B$. angustifolia extracts ranged from $13.85 \pm 1.22$ to $34.10 \pm 2.62 \mathrm{mg} / \mathrm{g}$. The hydroalcoholic extract had more phenolic content $(34.10 \pm 2.62 \mathrm{mg} / \mathrm{g})$ than other extracts. The quantitative alkaloid content ranged from $16.24 \pm 2.38$ to $31.86 \pm 1.88 \mathrm{mg} / \mathrm{g}$ (Table 2 ).

\section{Antioxidant activity}

The hydroalcoholic, ethyl acetate and hexane extracts of $B$. angustifolia were found to possess concentrationdependent scavenging activity. The mean $I_{50}$ values for the hydroalcoholic, ethyl acetate, and hexane extracts of $B$. angustifolia on superoxide radical were found as $237 \pm 0.56 \mu \mathrm{g}$, $294 \pm 0.22 \mu \mathrm{g}$, and $450 \pm 0.43 \mu \mathrm{g}$, respectively, and for ascorbic acid, it was $54.4 \pm 1.1 \mu \mathrm{g}$ (Figure 1, Table 3). The mean IC ${ }_{50}$ values for hydroxyl radicals were found as $265 \pm 0.82 \mu \mathrm{g}, 231 \pm 0.62 \mu \mathrm{g}$, and $369 \pm 0.52 \mu \mathrm{g}$, respectively, and for ascorbic acid it was $68.00 \pm 1.3 \mu$ g (Figure 2, Table 3). The mean $I_{50}$ values of DPPH radicals were found as $206 \pm 0.18 \mu \mathrm{g}, 272 \pm 0.14 \mu \mathrm{g}$, and $295 \pm 0.68$ $\mu \mathrm{g}$, respectively. The mean $\mathrm{IC}_{50}$ value of ascorbic acid was found as $22.0 \pm 0.5 \mu \mathrm{g}$ (Figure 3, Table 3). Among all the tested extracts, better free radical scavenging activity was found for the hydroalcoholic extract of $B$. angustifolia aerial parts.

\section{Acute toxicity studies}

There were no visible signs of toxicity and mortality, and no behavioral changes such as alertness, motor activity, breathlessness, restlessness, diarrhea, tremor, convulsion, and coma were observed at the administered doses. The animals were physically active and no deaths were recorded, even at doses of up to $2000 \mathrm{mg} / \mathrm{kg}$ body weight. Hence, all the tested extracts were considered as safe and nontoxic.

Table 2. Total phenolic and alkaloid contents $(\mathrm{mg} / \mathrm{gm})$ of $B$. angustifolia aerial parts' extracts

\begin{tabular}{llll} 
S. No & Name of the extract & $\begin{array}{l}\text { Total phenolic } \\
\text { content }(\mathrm{mg} / \mathrm{gm})\end{array}$ & $\begin{array}{l}\text { Total alkaloid content } \\
(\mathrm{mg} / \mathrm{gm})\end{array}$ \\
\hline & Hexane & $13.85 \pm 1.22$ & $16.24 \pm 2.38$ \\
1 & Ethyl acetate & $26.28 \pm 0.66$ & $22.40 \pm 1.36$ \\
3 & Hydroalcoholic & $34.10 \pm 2.62$ & $31.86 \pm 1.88$ \\
\hline
\end{tabular}

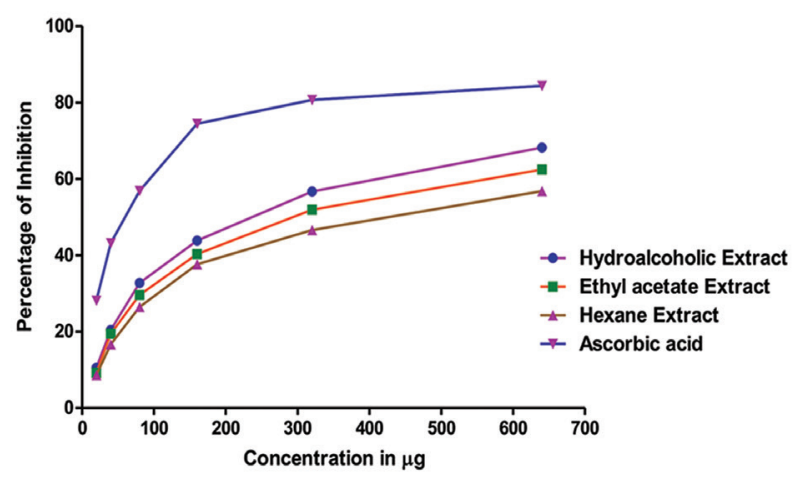

Figure 1. Concentration dependent percentage inhibition of different extracts of $B$. angustifolia on superoxide radical

\section{Hepatoprotective activity}

We examined the $B$. angustifolia aerial parts at three dose levels, $125 \mathrm{mg} / \mathrm{kg}, 250 \mathrm{mg} / \mathrm{kg}$, and $500 \mathrm{mg} / \mathrm{kg}$, which was assessed by measuring liver-related biochemical parameters (AST, ALT, ALP, total serum bilirubin, and total protein) levels for their hepatoprotective nature using TAA-induced hepatotoxicity in rats.

Group I, which was treated with vehicle, showed no significant changes in liver enzyme biomarker levels (AST, ALT, ALP, total bilirubin, and total protein). Group II was treated TAA, there were significant changes in levels of biomarker enzymes. The animals of Group III were administered TAA and then silymarin (Table 4). There were significant changes in biomarker enzymes levels compared with Group II rats' enzymes levels and the percentage protection offered by the silymarin against the changes in AST, ALT, ALP, total bilirubin, and total protein levels were $96.24 \%, 95.25 \%, 93.90 \%, 97.83 \%$, and $96.14 \%$, respectively.

The percentage protection produced by the hydroalcoholic extract (Groups IV, V and VI) on the enhancement of AST, ALT, ALP, total bilirubin, and total protein levels were $45.45 \%$, $45.01 \%, 38.35 \%, 35.38 \%$, and $32.87 \%$; $57.04 \%, 58.40 \%, 51.79 \%$, $48.21 \%$, and $46.05 \% ; 76.39 \%, 78.77 \%, 69.45 \%, 62.74 \%$, and $65.81 \%$, respectively.

The percentage protection produced by the ethyl acetate extracts (Groups VII, VIII, and IX) the enhancement of AST,

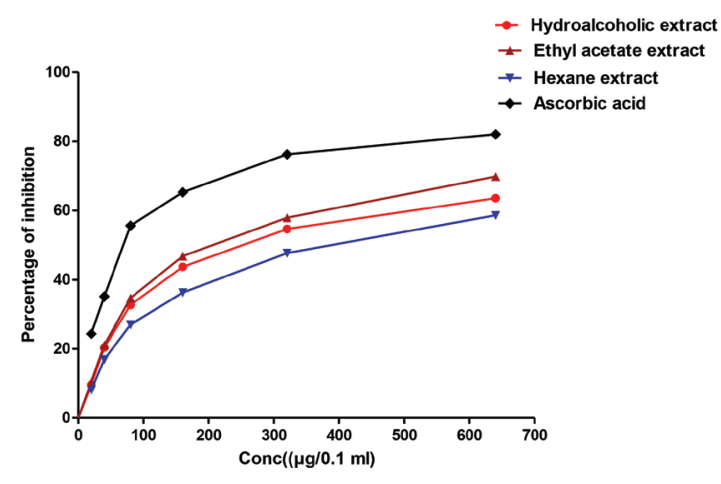

Figure 2. Concentration dependent percentage inhibition of different extracts of $B$. angustifolia on hydroxyl radical

Table 3. Fifty percent $\mathrm{IC}_{50}$ of different extracts of $B$. angustifolia against superoxide, hydroxyl and DPPH radicals

\begin{tabular}{llll} 
& \multicolumn{2}{l}{$50 \% \mathrm{IC}_{50}(\mu \mathrm{g} / \mathrm{mL})$} & \\
\cline { 2 - 4 } Name of the extract & $\begin{array}{l}\text { Superoxide } \\
\text { radical }\end{array}$ & $\begin{array}{l}\text { Hydroxyl } \\
\text { radical }\end{array}$ & $\begin{array}{l}\text { DPPH } \\
\text { radical }\end{array}$ \\
\hline Hydroalcoholic & $237 \pm 0.56$ & $265 \pm 0.82$ & $206 \pm 0.18$ \\
\hline Ethyl acetate & $294 \pm 0.22$ & $231 \pm 0.62$ & $272 \pm 0.14$ \\
\hline Hexane & $450 \pm 0.43$ & $369 \pm 0.52$ & $295 \pm 0.68$ \\
\hline Ascorbic acid & $54.4 \pm 1.1$ & $68.00 \pm 1.3$ & $22.0 \pm 0.5$ \\
\hline $\begin{array}{l}\text { DPPH: } 1 \text {-(2,6-dimethylphenoxy)-2-(3,4-dimethoxyphenylethylamino) } \\
\text { hydrochloride, } \text { IC }_{50}: \text { Inhibition concentration }\end{array}$ & & &
\end{tabular}


ALT, ALP, total bilirubin, and total protein levels were $43.03 \%$, $41.03 \%, 36.08 \%, 29.40 \%$, and $26.94 \%$; $54.20 \%, 55.41 \%, 49.57 \%$, $45.64 \%$, and $47.36 \% ; 66.36 \%, 67.38 \%, 60.04 \%, 59.32 \%$, and $61.20 \%$, respectively.

The percentage protection produced by the hexane extracts (Groups X, XI, and XII) on the enhancement of AST, ALT, ALP, total bilirubin, and total protein levels were $37.20 \%, 37.18 \%$, $30.55 \%, 25.98 \%$, and $24.97 \%$; 48.29\%, 47.72\%, 42.43\%, 40.51\%, and $40.78 \% ; 58.75 \%, 59.83 \%, 53.60 \%, 51.62 \%$, and $52.64 \%$, respectively.

The decrease in the AST, ALT, ALP and total bilirubin levels, and increase in levels of protein to normal, and percentage protection produced by the higher doses of the extracts were comparable to those of silymarin. Among all the extracts, the hydroalcoholic extracts of selected plants showed better activity (Table 5).

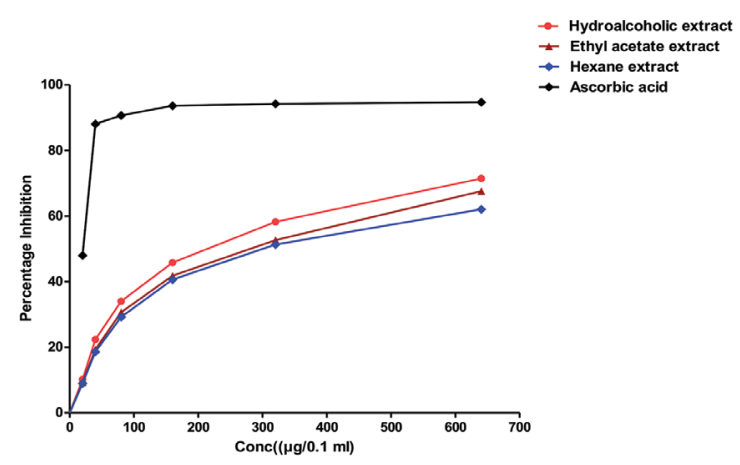

Figure 3. Concentration dependent percentage inhibition of different extracts of $B$. angustifolia on 1-(2,6-dimethylphenoxy)-2-(3,4dimethoxyphenylethylamino) propane hydrochloride radical

\section{Isolation of compounds}

The selected plant extracts (hexane, ethyl acetate, and hydroalcoholic) on thin-layer chromatography showed different spots with different retention factor values, but on the basis of biologic activities (antioxidant and hepatoprotective), the hydroalcoholic extract of $B$. angustifolia was used for the separation of compounds using column chromatography.

Column chromatography was performed using a standard procedure. Silica gel (Qualigens), 60-120 mesh was used as an absorbent for column chromatography. The column was eluted using hexane, hexane-ethyl acetate, ethyl acetate, and ethyl acetate-methanol mixtures by gradient. BA-1 and BA-2 compounds were isolated in the study.

Structure elucidation and characterization of compound BA-1

Compound BA-1 was isolated in the combination of hexane and ethyl acetate (95:05) in the form of colorless oil. The proton nuclear magnetic resonance (1H-NMR) spectrum (Figure 4) of compound BA- 1 in acetone exhibited signals due to olefinic

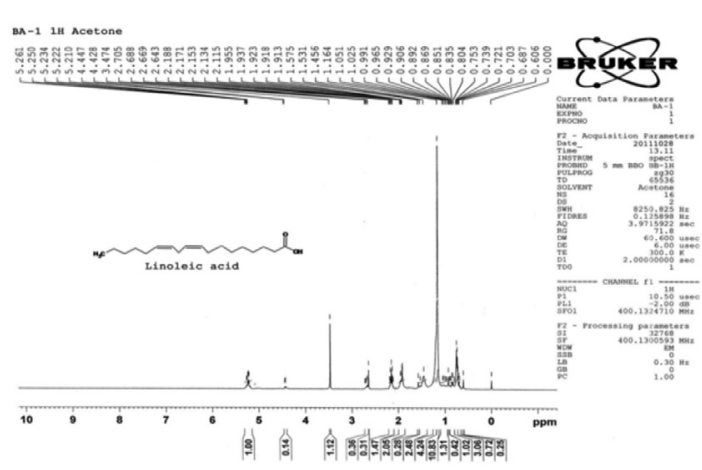

Figure 4. The proton nuclear magnetic resonance spectrum of compound BA-1

Table 4. Enzymes levels due to the effect of $B$. angustifolia extracts at different doses on TAA-induced liver toxicity in rats

\begin{tabular}{|c|c|c|c|c|c|c|}
\hline \multirow[b]{2}{*}{ Name of extract/compound } & \multirow{2}{*}{$\begin{array}{l}\text { Quantity of extract } \\
\text { (mg/kg b.w.) }\end{array}$} & \multicolumn{5}{|c|}{ Enzymes levels of TAA-induced hepatotoxicity } \\
\hline & & AST (U/L) & ALT (U/L) & ALP (U/L) & $\begin{array}{l}\text { Total bilirubin } \\
\text { ( } \mathrm{mg} / \mathrm{dL})\end{array}$ & $\begin{array}{l}\text { Total protein } \\
(\mathrm{g} / \mathrm{dL})\end{array}$ \\
\hline Normal (drug vehicle) & $2 \mathrm{~mL}$ & $96.17 \pm 6.97$ & $56 \pm 3.58$ & $217.5 \pm 2.59$ & $0.17 \pm 0.01$ & $7.40 \pm 0.46$ \\
\hline TAA & $50 \mathrm{mg}$ & $330.5 \pm 6.53$ & $173 \pm 5.22$ & $548.67 \pm 21.60$ & $2.123 \pm 0.27$ & $4.87 \pm 0.78$ \\
\hline \multirow[t]{2}{*}{ Silymarin } & $25 \mathrm{mg}$ & $87 \pm 2.83$ & $50.17 \pm 4.96$ & $196.00 \pm 5.10$ & $0.13 \pm 0.05$ & $7.50 \pm 0.37$ \\
\hline & $125 \mathrm{mg}$ & $224 \pm 3.03$ & $120.3 \pm 4.32$ & $421.67 \pm 6.65$ & $1.43 \pm 0.29$ & $5.7 \pm 0.37$ \\
\hline \multirow[t]{3}{*}{ Hydroalcoholic } & $250 \mathrm{mg}$ & $196.8 \pm 2.04$ & $104.67 \pm 3.01$ & $377.17 \pm 3.13$ & $1.18 \pm 0.27$ & $6.03 \pm 0.29$ \\
\hline & $500 \mathrm{mg}$ & $151.5 \pm 2.66$ & $80.8 \pm 2.32$ & $318.67 \pm 2.58$ & $0.9 \pm 0.18$ & $6.53 \pm 0.32$ \\
\hline & $125 \mathrm{mg}$ & $229.67 \pm 3.72$ & $125 \pm 4.00$ & $429.17 \pm 2.32$ & $1.55 \pm 0.23$ & $5.55 \pm 0.22$ \\
\hline \multirow[t]{3}{*}{ Ethylacetate } & $250 \mathrm{mg}$ & $203.5 \pm 4.28$ & $108.17 \pm 2.23$ & $384.5 \pm 4.97$ & $1.23 \pm 0.24$ & $6.07 \pm 0.18$ \\
\hline & $500 \mathrm{mg}$ & $175 \pm 2.83$ & $94.17 \pm 3.71$ & $349.8 \pm 2.14$ & $0.97 \pm 0.18$ & $6.42 \pm 0.35$ \\
\hline & $125 \mathrm{mg}$ & $243.3 \pm 4.46$ & $129.5 \pm 2.43$ & $447.5 \pm 3.21$ & $1.62 \pm 0.27$ & $5.5 \pm 0.37$ \\
\hline \multirow[t]{2}{*}{ Hexane } & $250 \mathrm{mg}$ & $217.3 \pm 3.50$ & $117.17 \pm 2.23$ & $408.17 \pm 2.79$ & $1.33 \pm 0.20$ & $5.9 \pm 0.41$ \\
\hline & $500 \mathrm{mg}$ & $192.8 \pm 2.64$ & $103 \pm 2.19$ & $371.17 \pm 2.40$ & $1.12 \pm 0.17$ & $6.2 \pm 0.34$ \\
\hline
\end{tabular}

TAA: Thioacetamide, AST: Aspartate aminotransferase, ALT: Alanine aminotransferase, ALP: Alkaline phosphatase 
Table 5. Percentage (\%) protection of enzymes levels due to the effect of $B$. angustifolia extracts at different doses on TAA-induced liver toxicity in rats

\begin{tabular}{|c|c|c|c|c|c|c|}
\hline \multirow[b]{2}{*}{ Name of extract } & \multirow[b]{2}{*}{ Quantity of extract } & \multicolumn{5}{|c|}{ Percentage protection on enzymes levels of TAA-induced hepatotoxicity } \\
\hline & & AST $(U / L)$ & ALT $(U / L)$ & ALP $(U / L)$ & $\begin{array}{l}\text { Total bilirubin } \\
(\mathrm{mg} / \mathrm{dL})\end{array}$ & Total protein $(\mathrm{g} / \mathrm{dL})$ \\
\hline \multirow[t]{2}{*}{ Silymarin } & 50 mg/kg b.w. & 96.24 & 95.25 & 93.90 & 97.83 & 96.14 \\
\hline & 125 mg/kg b.w. & $45.45^{\star \star}$ & $45.01^{\star *}$ & $38.35^{\star \star}$ & $35.38^{\star \star}$ & $32.87^{* *}$ \\
\hline \multirow[t]{3}{*}{ Hydroalcoholic } & 250 mg/kg b.w. & $57.04^{* *}$ & $58.40 * *$ & $51.79 * *$ & $48.21^{*}$ & $46.05^{\star}$ \\
\hline & 500 mg/kg b.w. & $76.39 * \star$ & $78.77^{\star \star \star}$ & $69.45^{\star \star}$ & $62.74^{\star *}$ & $65.81^{\star \star \star}$ \\
\hline & 125 mg/kg b.w. & $43.03^{*}$ & $41.03^{\star *}$ & $36.08^{*}$ & $29.40 *$ & $26.94^{*}$ \\
\hline \multirow[t]{3}{*}{ Ethylacetate } & 250 mg/kg b.w. & $54.20^{*}$ & $55.41^{* *}$ & $49.57^{\star *}$ & $45.64^{*}$ & $47.36^{* *}$ \\
\hline & 500 mg/kg b.w. & $66.36^{* *}$ & $67.38^{\star * *}$ & $60.04^{* *}$ & $59.32 * *$ & $61.20 * *$ \\
\hline & 125 mg/kg b.w. & $37.20^{*}$ & $37.18^{*}$ & $30.55^{\star}$ & $25.98^{*}$ & $24.97^{*}$ \\
\hline \multirow[t]{2}{*}{ Hexane } & 250 mg/kg b.w. & $48.29^{\star}$ & $47.72^{\star \star}$ & $42.43^{\star \star}$ & $40.51^{*}$ & $40.78^{\star \star}$ \\
\hline & 500 mg/kg b.w. & $58.75^{\star \star}$ & $59.83^{* * *}$ & $53.60 * *$ & $51.62^{\star \star}$ & $52.64^{\star * *}$ \\
\hline
\end{tabular}

TAA: Thioacetamide, AST: Aspartate aminotransferase, ALT: Alanine aminotransferase, ALP: Alkaline phosphatase ${ }^{* * *} p<0.001,{ }^{* *} p<0.01,{ }^{*} p<0.05$

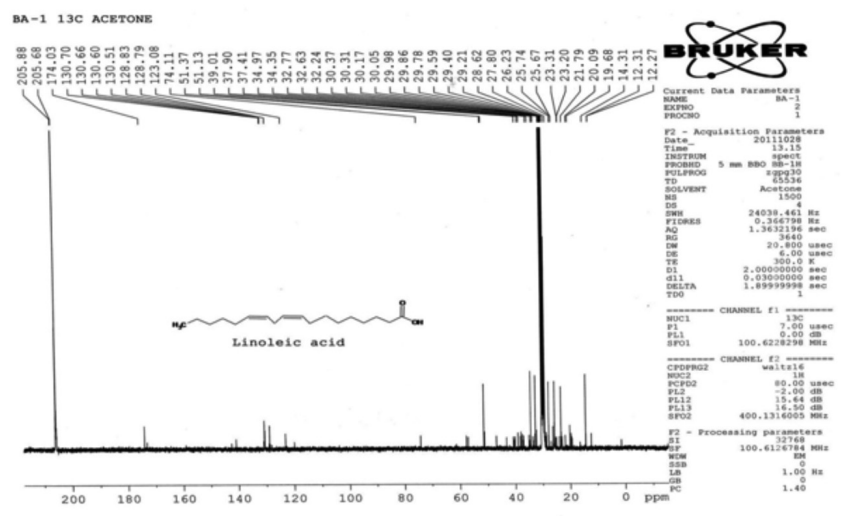

Figure 5. 13C-nuclear magnetic resonance spectrum of compound BA-1

protons at $\delta 5.3 \sim 5.4$, triplet methylene protons at $\delta 2.8,11$ methylene protons at $\delta 2.3,2.0,1.6$ and 1.3 , and methyl protons at $\delta .8$. These signals were well matched to corresponding signals of linoleic acid, suggesting that this compound was linoleic acid or an unsaturated fatty acid. In the electrospray ionisation-mass measurement, its molecular weight was determined as 280 through a quasi-molecular ion peak at $\mathrm{m} / \mathrm{z}$ $279[\mathrm{M}-\mathrm{H}]-$ in the negative mode. This molecular weight was consistent with linoleic acid. Therefore, compound BA-1 was identified as linoleic acid. The introduction of a second doublebond to give linoleic acid or methyl linoleate (methyl $9(Z), 12(Z)$ octadecadienoate) gives rise to a peak at $2.8 \mathrm{ppm}$ caused by the bis-allylic protons located at C11. The theoretical integration value of the olefinic protons increases to four, whereas that of the large methylene peak decreases further to 14 .

Generally, many effects observed in $1 \mathrm{H}-\mathrm{NMR}$ are also found in 13C-NMR (Figure 5). For example, the methyl and methylene

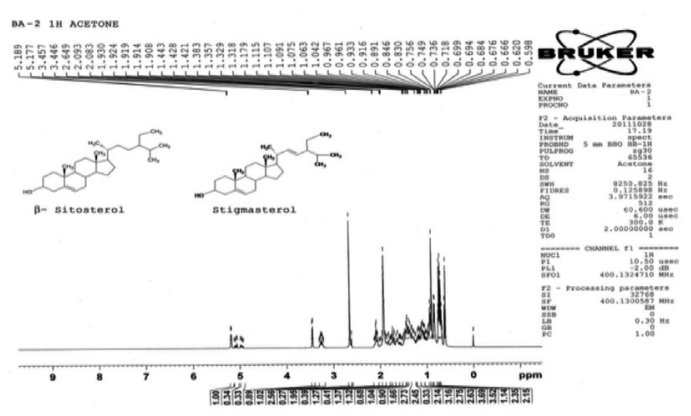

Figure 6. The proton nuclear magnetic resonance spectrum of compound BA-2

signals are up field in the spectrum, and signals of olefinic carbons are farther downfield. The number and nature of double-bonds affects the chemical shifts, as do the proximity of multiple double-bonds to each other and the presence of functional groups.

\section{Structural elucidation of compound BA-2}

Compound BA-2 was isolated as a white solid with colorless needles, a mixture containing two sterolic compounds from the hexane soluble in combination of hexane and ethyl acetate (90:10). The mixture gave a positive color reaction with sulphuric acid indicating the sterolic nature. The molecular formula $\mathrm{C}_{29} \mathrm{H}_{48} \mathrm{O}$ (stigmasterol) and $\mathrm{C}_{29} \mathrm{H}_{50} \mathrm{O}$ ( $\beta$-sitosterol) were established showing molecular ion peak [M]+ at $\mathrm{m} / z$ 412.3920, [M] ${ }^{+}$at 414, respectively, from the previous data as explained earlier. The $1 \mathrm{H}$ and 13C-NMR data are provided in Figures 6 and 7. 


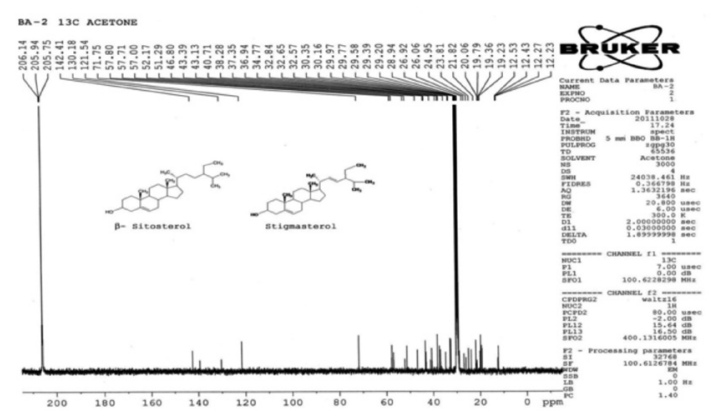

Figure 7. 13C-nuclear magnetic resonance spectrum of compound BA-2

\section{DISCUSSION}

Modern medicine significantly decreased mortality from different diseases compared with before the mid-nineteenth century. However, these developed medicines that cure diseases cause different adverse effects with long-term use, and their injudicious use has led to the development of drugresistant diseases. ${ }^{22,23}$ Medicinal plants have been used for the prevention and treatment of diseases for a long time. ${ }^{24,25}$ There is a necessity to identify new bioactive molecules or drugs through science and technology from natural sources including medicinal plants, which are safer with no adverse effects and low cost. ${ }^{24}$ In recent years, many researchers have reported on new drugs and validated traditional medicinal plants. ${ }^{25}$ The results of the present study provide scientific evidence for the traditional use of $B$. angustifolia..$^{10-12}$ The qualitative phytochemical analysis and quantification of total phenolic and alkaloid contents and biologic activities were studied for $B$. angustifolia. Qualitative phytochemical screening of different extracts revealed the presence of different phytochemical constituents such as steroids, terpenoids, phenols, flavonoids, alkaloids, glycosides, phenols, tannins, carbohydrates, oils, and amino acids. The extracts on qualitative analysis on phenolic and alkaloid contents of hydroalcoholic extract showed greater content in it compared with other extracts.

Many investigations have reported that medicinal plants contain a wide variety of natural bioactive compounds that possess biologic activities. ${ }^{26-30}$ Accordingly, the extracts were tested for their antioxidant capacity and hepatoprotective activity on TAAinduced liver toxicity. Many investigations explained the positive correlation between oxidative stress and liver toxicity. ${ }^{31}$ The extracts of $B$. angustifolia showed a dose-dependent percentage inhibition on tested free radicals, but it was lower activity compared with ascorbic acid; as the concentration increases, the percentage inhibition may increase. The extracts reduced the formation of superoxide free radicals in the tested method; superoxide radical is the main free radical for oxidative stress by being involved in the formation of other free radicals. ${ }^{32}$ At the same time, the extracts also showed hepatoprotective activity on TAA-induced liver toxicity in rats. ${ }^{19-21}$ TAA-induced liver toxicity was established as the method to evaluate natural products for hepatoprotective activity and its mechanism involved for liver toxicity by damaging the mitochondria and dysfunction of intracellular organelles of hepatic cells. This ultimately leads to an increase in the amount of bile acid, greater amounts of which generally promote liver damage by oxidative stress ${ }^{31}$ and often elevate liver biomarker enzymes in the body i.e. AST, ALT, ALP, total bilirubin, and total protein. Thus, biomarker enzymes were analyzed in the present study. The results of the hepatoprotective activity in the present study indicate that $B$. angustifolia extracts possesses moderate hepatoprotective activity compared with the standard drug silymarin. The extracts were significantly ( $p<0.05)$ normalized the elevated biomarker enzymes levels compared with the toxic group (Group II). As mentioned earlier, there may be a relationship between the antioxidant activity and hepatoprotective activity of $B$. angustifolia extracts. Among all the extracts, the hydroalcoholic extract showed more activities and higher phenolic and alkaloid contents. From this point of view, we tried to isolate new bioactive molecules/compounds using hydroalcoholic extract using column chromatography, but unfortunately, known compounds i.e. mixtures of stigmasterol and $\beta$-sitosterol and linolenic acid were isolated. However, these compounds are reported from this plant species for the first time. The isolated compounds, stigmasterol and $\beta$-sitosterol were isolated from $B$. angustifolia are may be responsible for the activities of selected plants because there were some earlier reports of different biologic activities of these compounds ${ }^{33-39}$ or some other unknown compounds may be acting individually or may be synergistically.

\section{CONCLUSIONS}

The results of the present study provide evidence about traditional medicinal use of $B$. angustifolia, which is a traditional medicinal plant in India, and isolated known compounds stigamsterol and $\beta$-sitosterol from hydroalcoholic extract, were first reported from this species and maybe from this genus. Further research is needed to evaluate more pharmacologic activities of $B$. angustifolia and to isolate the more bioactive compounds through chromatographic techniques. Standardization of these isolates can be carried out by obtaining a chemical fingerprint/profile.

\section{ACKNOWLEDGEMENTS}

The authors are acknowledged to the authorities of Andhra University in providing the necessary facilities and also to the Rajiv Gandhi National Fellowship (RGNF)-UGC [No: F. 161577(SC)/2010 (SA-III)], New Delhi for financial support which enabled me to successfully complete the research.

Conflicts of Interest: No conflict of interest was declared by the authors.

\section{REFERENCES}

1. Azaizeh H, Saad B, Khalil K, Said O. The State of the Art of Traditional Arab Herbal Medicine in the Eastern Region of the Mediterranean: A Review. Evid Based Complement Alternat Med. 2006;3:229-235.

2. Zaslawski C, Davis S. The ethics of complementary and alternative medicine research: a case study of Traditional Chinese Medicine at the University of Technology, Sydney. Monash Bioeth Rev. 2005;24:52-60. 
3. Pefile S. South African legislation on traditional medicine. Science and Development Network, 2005.

4. Lam TP. Strengths and weaknesses of traditional Chinese medicine and Western medicine in the eyes of some Hong Kong Chinese. J Epidemiol Community Health. 2001;55:762-765.

5. Pandey MM, Subha Rastogi, Rawat AK. Indian Traditional Ayurvedic System of Medicine and Nutritional Supplementation. Evid Based Complement Alternat Med. 2013;2013:376327.

6. Cheng YC. Why and how to globalize Traditional Chinese Medicine. J Tradit Complement Med. 2011;1:1-4.

7. Eteraf-Oskouei T, Najafi M. Traditional and Modern Uses of Natural Honey in Human Diseases: A Review. Iran J Basic Med Sci. 2013;16:731742.

8. Carleton BC, Smith A. Drug safety: Side effects and mistakes or adverse reactions and deadly errors? BC Med J. 2006;48:329-333.

9. Cox PA, Balick MJ. The ethnobotanical approach to drug discovery. Sci Am. 1994:270:82-87.

10. Chaudhuri RD. Herbal Drugs Industry: practical approach to industrial pharmacognosy. New Delhi: Eastern Publishers; 1996:491.

11. Prasad N, Siddiqui MZ, Chowdhury AR, Thomas M. Buchanania lanzan: a species of enormous potentials. World J Pharm Scie. 2014;2:374-379.

12. Kirankumar H, Manjunatha JR, Kuppasth IJ. Comparative Study on Diuretic Effect of Buchanania angustifolia Roxb, and Buchanania lanzan Spreng. Fruit Extracts and Fractions. J App Pharm Sci. 2014;4:59-63.

13. Swamy TR. Phytochemical and biological evaluation of three Indian traditional medicinal plants, PhD Thesis, Andhra University, Visakhapatnam, Andhra Pradesh, India; 2015.

14. Mallikarjuna Rao T. Biological and preliminary phytochemical evaluation of three folklore medicinal plants, Melochia corchorifolia L, Chrozophora rottleri (Geiseler) A. Juss. Ex Spreng and Spilanthes acmella L., PhD Thesis, Andhra University, Visakhapatnam, Andhra Pradesh, India; 2013.

15. Singleton VL, Rossi JA. Colorimetry of total phenolics with phosphomolybdic acid phosphotungstic acid reagents. Am J Enol Vitic. 1965;16:144-158.

16. Shamsa F, Monsef H, Ghamooshi R, Verdian-Rizi M. Spectrophotometric determination of total alkaloids in some Iranian medicinal plants. Thai $\mathrm{J}$ Pharm Sci. 2008;32:17-20.

17. Rao BG, Rao YV, Rao TM. Hepatoprotective and antioxidant capacity of Melochia corchorifolia Extracts. Asian Pac J Trop Med. 2013;6:537-543.

18. Rao MT, Rao BG, Rao YV. Antioxidant activity of Spilanthes acmella extracts. International Journal of Phytopharmacology. 2012;3:216-220.

19. Moiz Mumtaz. Principles and Practice of Mixtures Toxicology. Chapter 6: Toxicodynamic Interactions, Wiley-VCH Verlag GmbH\&Co. KGaA. 2010:159-206.

20. Grattagliano I, Bonfrate L, Diogo CV, Wang HH, Wang DQ, Portincasa $P$. Biochemical mechanisms in drug-induced liver injury. World $\mathrm{J}$ Gastroenterol. 2009;15:4865-4876.
21. Staňková $P$, Kučera $O$, Lotková $H$, Roušar $T$, Endlicher R, Cervinková Z. The toxic effect of thioacetamide on rat liver in vitro. Toxicology In Vitro. 2010;24:2097-2103.

22. Phillipson JD. Fifty years of medicinal plant research: every progress in methodology is a progress in science. Planta Med. 2003;69:491-493.

23. Oksman-Caldentey KM, Inze D. Plant cell factories in the post-genomic era: New ways to produce designer secondary metabolites. Trends Plant Sci. 2004;9:433-440.

24. Sharma RK, Arora R. Herbal Drugs. A Twenty First Century Perspective. Jaypee Brothers Medical Publishers, New Delhi, India; 2006:666.

25. Li XZ, Zhang SN, Liu SM, Lu F. Recent advances in herbal medicines treating Parkinson's disease. Fitoterapia. 2013;84:273-285.

26. Arora R. Herbal Radiomodulators: Applications in Medicine, Homeland Defence and Space. CABI Publishing, Wallingford, Oxon, UK. 2008:332.

27. Lamba SS, Buch KY, Lewis H, Lamba J. Phytochemicals as potential hypoglycemic agents. Studies in Natural Products Chemistry. 2000;21:457-496.

28. Marles RJ, Farnsworth NR. Antidiabetic plants and their active constituents. Phytomedicine. 1995;2:137-189.

29. Catapano AL. Antioxidant effect of flavonoids. Angiology. 1997;48:39-44.

30. Boyer J, Liu RH. Apple phytochemicals and their health benefits. Nutr J. 2004;3:5.

31. Ali S, Ansari KA, Jafry MA, Kabeer H, Diwakar G. Nardostachys jatamansi protects against liver damage induced by thioacetamide in rats. J Ethnopharmacol. 2000;71:359-363.

32. Lobo V, Patil A, Phatak A, Chandra N. Free radicals, antioxidants and functional foods: Impact on human health. Pharmacogn Rev. 2010;4:118126.

33. Harborne JB, Williams CA. Advances in flavonoid research since 1992. Phytochemistry. 2000;55:481-504.

34. Panda S, Jafri M, Kar A, Meheta BK. Thyroid inhibitory, antiperoxidative and hypoglycemic effects of stigmasterol isolated from Butea monosperma. Fitoterapia. 2009;80:123-126.

35. Gabay O, Sanchez C, Salvat C, Chevy F, Breton M, Nourissat G, Wolf C, Jacques C, Berenbaum F. Stigmasterol: a phytosterol with potentialanti-osteoarthritic properties. Osteoarthritis Cartilage. 2010;18:106-116.

36. Gupta MB, Nath R, Srivastava N, Shanker K, Kishor K, Bhargava KP. Antiinflammatory and antipyretic activities of beta-sitosterol. Planta Med. 1980;39:157-163.

37. Salvador MJ, Zucchi OLAD, Candido RC, Ito IY, Dias DA. In vitro antimicrobial activity of crude extracts and isolated constituents of Alternanthera maritima (Amaranthaceae). Pharmaceutical Biology. 2004:42:138-148.

38. Letawe C, Boone M, Pierard GE. Digital image analysis of the effect of topically applied linoleic acid on acne microcomedones. Clin Exp Dermatol. 1998;23:56-58.

39. Cunnane S, Anderson M. Pure linoleate deficiency in the rat: influence on growth, accumulation of n-6 polyunsaturates, and (1-14C) linoleate oxidation. J Lipid Res. 1997;38:805-812. 